\title{
Studi Karakteristik Sifat Kualitatif Dan Morfometrik Induk Ayam Kampung Dengan Berbagai Tipe Jengger Di Pulau Lombok
}

\section{(A Study on Characteristic of Qualitative Traits And Morphometric Of Kampung Chickens With Various Comb-Types In Lombok Island)}

Lestari, Maskur, R. Jan, Tapaul Rozi, Lalu M. Kasip, M. Muhsinin

Fakultas Peternakan Universitas Mataram, J1. Majapahit Mataram Lombok. Nusa Tenggara Barat. 83125

Email: taribambang@yahoo.com

Diterima : 5 Maret 2020/Disetujui : 18 Mei 2020

\begin{abstract}
ABSTRAK
Penelitian ini bertujuan untuk mengidentifikasi keragaman sifat kualitatif dan morfometrik induk ayam kampung berdasarkan tipe jengger di Pulau Lombok. Materi yang digunakan yaitu induk ayam kampung yang dipelihara secara tradisional sebanyak 417 ekor. Metode yang digunakan yaitu survei. Penentuan lokasi dilakukan secara purposif sampling dan pengambilan sampel dilakukan secara random sampling. Data kualitatif meliputi tipe jengger, warna bulu, warna kulit, warna kaki. Data morfometrik meliputi tinggi jengger, panjang shank, panjang tibia, panjang femur, jarak antar tulang pubis, jarak antara tulang pubis dengan tulang dada dan bobot badan. Data dianalisis menggunakan analisis statistik sederhana. Hasil penelitian menemukan 4 (empat) tipe jengger walnut 36.45 persen, tunggal 30.45 persen, pea 24.46 persen dan rose 8.64 persen. Warna bulu yaitu hitam, keemasan, lurik dan putih. Warna bulu putih hanya ditemukan pada ayam jengger pea. Warna cuping telinga yaitu merah dan putih. Warna shank yaitu hitam, putih dan kuning. Warna kulit yaitu kuning dan putih. Morfometrik ayam kampung tertinggi dicapai ayam tipe jengger rose yaitu tinggi jengger $12.16 \pm 2.78 \mathrm{~mm}$, panjang shank $74.26 \pm 11.62 \mathrm{~mm}$, panjang tibia $88.47 \pm 11.87 \mathrm{~mm}$, panjang femur $82.11 \pm 12.45 \mathrm{~mm}$, jarak dua tulang pubis $35.95 \pm 7.32 \mathrm{~mm}$, jarak tulang pubis dengan tulang dada $54.74 \pm 9.86 \mathrm{~mm}$ dan bobot badan 1658.19+339.63gram.
\end{abstract}

Kata kunci : sifat kualitatif, morfometrik, induk, ayam kampung, tipe jengger.

\begin{abstract}
This study aimed to identify the diversity of qualitative and morphometric traits of Kampung chickens based on the comb-types in Lombok Island. Four hundred and seventeen Kampung chickens that are maintained traditionally were used in this study. The method used was a survey. The determination of location was done by purposive sampling, and samples taken were selected by random sampling. Qualitative data included comb-type, fur color, skin color, and foot color. Morphometric data included comb height, shank length, tibia length, femur length, the distance between pubic bones, the distance between the pubic bone and breastbone and body weight. Data were analyzed using simple statistical analysis. The results show that there were 4 (four) types of comb namely walnut comb (36.45 percent), single (30.45 percent), pea (24.46 percent) and rose (8.64 percent). Fur colors found were black, golden, striated and white. White fur color was only found in pea combs. The earlobe colors were red and white. Shank colors were black, white and yellow. The skin colors were yellow and white. The highest morphometrics of Kampung chicken was found in chickens with the type of rose comb which showed comb height of $12.16+2.78 \mathrm{~mm}$, shank length of $74.26+11.62 \mathrm{~mm}$, tibia length of $88.47+11.87 \mathrm{~mm}$, femur length of $82.11+12.45 \mathrm{~mm}$, distance of two pubic bones of $35.95+$ $7.32 \mathrm{~mm}$ ), distance between the pubic bone and breastbone of $54.74+9.86 \mathrm{~mm}$ and body weight of $1658.19+339.63$ gram.
\end{abstract}

Keywords: qualitative trait, morphometrics, hen, Kampung chicken, comb-type. 


\section{PENDAHULUAN}

Ayam kampung merupakan ternak unggas andalan yang mempunyai potensi tinggi dalam menyambung ketersediaan pangan asal hewan dalam bentuk daging dan telur ayam. Ayam kampung banyak digemari konsumen karena memiliki cita rasa yang khas dan dapat ditemukan di berbagai wilayah di Indonesia. Ayam kampung di pulau Lombok memiliki kontribusi besar sebagai bahan dasar ayam Taliwang, yaitu produk pangan lokal di Kota Mataram. Permintaan ayam Kampung untuk ayam Taliwang terus meningkat pada setiap restoran yaitu sebanyak 585 ekor/hari (Akhsan,1995), 400 ekor/hari (Awaludin, 2012) serta $1.372 .800 \mathrm{~kg} /$ hari (Zaenuri, dkk., 2016).

Ayam kampung merupakan ternak unggulan daerah dan nasional, yang juga merupakan kekayaan alam dunia. Oleh karena itu Indonesia mempunyai tanggung jawab moral untuk melestarikan sumberdaya genetik ternak unggas lokal secara mantap dan berkelanjutan. Menurut Zein dan Sulandari (2008), akibat pemotongan yang tidak diimbangi peningkatan produksi, ayam kampung Lombok mengalami deversitas genetic dan ekspansi populasi yang sangat tinggi. Eksploitasi spesies flora dan fauna berlebihan akan menimbulkan kelangkaan dan kepunahan spisies (Sutoyo, 2010).

Upaya melestarikan unggas lokal dilakukan dengan memperhatikan habitat asli dan pewilayahannya terutama untuk sistem penangkaran insitu, yaitu mempertahankan populasi dan genetik dihabitat aslinya secara terprogram. Pelestarian sumberdaya genetik unggas lokal dapat dilaksanakan apabila telah diidentifikasi karakteristiknya (Samariyanto, 2005).
Ridhwan (2012) menyatakan bahwa pada makhluk hidup terjadi keberagaman pada perbedaan warna, ukuran, bentuk, jumlah, tekstur, penampilan dan sifat-sifat lainnya. Iskandar dkk. (1991) yang disitasi Melani (2010) menyatakan bahwa keragaman karakteristik ayam kampung sebagai informasi dalam membangun tatalaksana pemeliharaan secara khusus di setiap daerah. Tampilan individu ditentukan oleh kemampuannya dan kesempatan yang ada (Hardjosubroto,1994).

Ayam kampung sebagai ayam yang tidak mempunyai ciri-ciri khas tertentu, saat ini banyak terlihat berkeliaran di desa-desa di Indonesia. Sartika dkk. (2013) yang disitasi Mayora (2017) mengemukakan bahwa ayam kampung merupakan hasil domestikasi ayam hutan merah dengan fenotip dan genotip yang sangat beragam.

Keragaman sifat fenotip dan genotip dapat dilihat dari bentuk jengger. Jengger sebagai identitas potensi produksi dan reproduksi ayam kampung. Jengger yang tumbuh dan berkembang dengan baik menunjukkan kinerja produksi dan reproduksi yang tinggi. Menurut Lestari, dkk. (2007) dan Subekti dan Arlina (2011), ada empat macam tipe jengger ayam kampung yaitu rose, pea, walnut dan tunggal. Ukuran dan tekstur jengger sangat penting untuk seleksi bibit. Jengger yang tumbuh dan berkembang dengan baik menunjukkan kinerja produksi dan reproduksi yang tinggi. Di dalam keragaman produksi dan reproduksi ayam kampung terdapat sifat-sifat unggul, yang mungkin dapat dimanfaatkan di masa mendatang.

Suatu metode pengukuran terhadap variasi dan perubahan bentuk 
serta ukuran tubuh dari suatu organisme disebut morfometri (Zelditch et al., 2004). Pengukuran morfometrik dapat membantu proses seleksi dan perkawinan silang ternak antar bangsa maupun jenis (Kurnianto et al., 2013). Penelitian ini merupakan langkah awal dalam menentukan kriteria seleksi yang tepat untuk pelaksanaan program seleksi atau perbaikan mutu yang berkelanjutan. Tujuan penelitian ini adalah untuk mendapatkan data karakteristik sifat-sifat kualitatif dan morfometrk produksi ayam Kampung yang dipelihara secara tradisional di Pulau Lombok berdasarkan tipe jengger.

\section{METODE PENELITIAN}

\section{Alat dan Bahan}

Alat yang digunakan yaitu jangka sorong merk Modern kapasitas $30 \mathrm{~cm}$ dengan kepekaan $0.01 \mathrm{~cm}$; timbangan elektronik merk Camry kapasitas $5 \mathrm{~kg}$ dengan kepekaan $0.01 \mathrm{~kg}$ dan kamera HP merk Samsung Galaxy A6. Materi yang digunakan adalah ayam kampung betina dewasa yang dipelihara secara tradisional se pulau Lombok sebanyak 417 ekor, dan jantan sebanyak 395 ekor.

\section{Metode}

Penelitian dilakukan menggunakan metode survey di lima daerah yaitu Kota Mataram, Lombok Barat, Lombok Tengah, Lombok Timur dan Lombok Utara. Setiap daerah diambil 3 kecamatan, setiap kecamatan diambil 3 desa, setiap desa diambil 3 dusun dan setiap dusun diambil 3 peternak yang memiliki ayam kampung betina dewasa. Pemilihan lokasi dilakukan secara purposive sampling, yaitu cara pengambilan daerah penelitian dengan mempertimbangkan alasan yang diketahui dari daerah penelitian tersebut (Singarimbun dan Efendi, 1989).

\section{HASIL DAN PEMBAHASAN}

Sifat kualitatif dan morfometrik ayam kampung di Pulau Lombok sangat variatip. Sartika dan Iskandar (2007) menyatakan bahwa ayam kampung sebagai ayam yang tidak mempunyai ciriciri khas tertentu. Warwick et al. (1995) menyatakan bahwa penampilan suatu sifat tergantung pada gen-gen yang dimiliki ternak, tetapi keadaan lingkungan yang menunjang diperlukan untuk memberikan kesempatan penampilan suatu sifat secara penuh. Faktor genetis menjadi perhatian utama untuk memperbaiki kualitas ternak, yakni seleksi menuju satu tujuan antara lain seleksi kearah produksi daging dan telur (Samariyanto, 2005).

Sifat kualitatif (Tabel 1) meliputi tipe jengger, warna bulu, warna cuping, warna shank dan warna kulit. Hasil penelitian menemukan empat macam tipe jengger yaitu walnut (36.45\%), tunggal (30.45\%), pea (24.46\%) dan rose (8.64\%). Suryo (1994) menyatakan bahwa William Bateson dan R.C. Punnet mengawinkan ayam Wyandotte berjengger mawar (Rpp) dengan ayam Brahma berjengger ercis (rrP-) mendapatkan F1 berjengger walnut (P-R-). Kemudian ayam-ayam F1 tersebut dibiarkan kawin sesamanya menghasilkan F2 dengan empat macam jengger yaitu walnut, mawar, ercis tunggal. Jengger mawar ditentukan oleh gen dominan R, jengger ercis oleh gen dominan $P$. Jengger walnut (P-R-) dan tunggal (pprr) merupakan jengger baru. Jull (1951) yang disitasi Syakir (2018) menyatakan bahwa jengger ros dan kapri bersifat dominan terhadap jengger tunggal. Jika gen ros dan Pea bertemu maka akan terbentuk jengger 
walnut yang dominan terhadap jengger rose, pea dan tunggal, jengger walnut yang dominan terhadap jengger ros, kapri, dan tunggal.

Williamson dan Payne (1993) menyatakan sebagian besar ayam didomestikasi memiliki bentuk jengger tunggal, seperti yang dimiliki ayam Hutan Merah, ayam Hutan Abu-Abu dan ayam Hutan Ceylon. Lebih lanjut dijelaskan bahwa selama domestikasi terjadi mutasi sehingga ada perubahan-perubahan bentuk jengger di antaranya bentuk rose, pea, walnut, $\mathrm{V}$ dan bahkan tidak berjengger sama sekali.

Tabel 1. Sifat Kualitatip dan Morfometrik Ayam Kampung Di Pulau Lombok

\begin{tabular}{|c|c|c|c|c|}
\hline \multirow[t]{2}{*}{ VARIABEL } & \multicolumn{4}{|c|}{ TIPE JENGGER } \\
\hline & $\begin{array}{c}\text { Pea } \\
(24.46 \%)\end{array}$ & $\begin{array}{c}\text { Rose } \\
(8.64 \%)\end{array}$ & $\begin{array}{c}\text { Walnut } \\
(36.45 \%)\end{array}$ & $\begin{array}{c}\text { Tunggal } \\
(30.45 \%)\end{array}$ \\
\hline \multicolumn{5}{|l|}{ Sifat Kualitatip : } \\
\hline - Warna bulu : & & & & \\
\hline a. $\operatorname{Hitam}(\%)$ & 7.19 & 1.67 & 10.55 & 8.39 \\
\hline b. $\quad$ Liar $(\%)$ & 2.91 & 1.24 & 6.23 & 4.09 \\
\hline c. $\operatorname{Emas}(\%)$ & 3.11 & 2.15 & 4.84 & 5.51 \\
\hline d. Lurik (\%) & 6.23 & 1.91 & 8.36 & 5.51 \\
\hline e. Abu $(\%)$ & 1.19 & 1.67 & 6.47 & 6.95 \\
\hline f. Putih (\%) & 3.83 & & & \\
\hline - Warna Cuping : & & & & \\
\hline a. $\operatorname{Merah}(\%)$ & 17.5 & 4.79 & 22.3 & 18.46 \\
\hline b. Putih (\%) & 6.96 & 3.85 & 14.15 & 11.99 \\
\hline - Warna Shank: & & & & \\
\hline a. $\operatorname{Hitam}(\%)$ & 2.39 & 3.11 & 11.51 & 11.51 \\
\hline b. Putih (\%) & 5.99 & 2.18 & 11.03 & 8.64 \\
\hline c. Kuning & 16.08 & 3.35 & 13.9 & 10.31 \\
\hline - Warna Kulit : & & & & \\
\hline a. Kuning (\%) & 9.59 & 4.79 & 15.78 & 14.14 \\
\hline b. Putih (\%) & 14.87 & 3.85 & 20.67 & 16.31 \\
\hline \multicolumn{5}{|l|}{ Morfometrik : } \\
\hline - Tinggi Jengger (mm) & $9.60 \pm 2.4$ & $12.16 \pm 2.78$ & $6.04 \pm 3.21$ & $9.91 \pm 3.66$ \\
\hline - Panjang shank (mm) & $73.96 \pm 10.14$ & $74.26 \pm 11.62$ & $71.77 \pm 9.83$ & $73.74 \pm 10.92$ \\
\hline - Panjang Tibia (mm) & $86.77 \pm 14.18$ & $88.47 \pm 11.87$ & $85.65 \pm 12.85$ & $87.56 \pm 13.17$ \\
\hline - Panjang Femur (mm) & $82.08 \pm 12.54$ & $82.11 \pm 12.45$ & $75.84+13.27$ & $81.09+15.49$ \\
\hline - Jarak dua tl pubis (mm) & $35.25 \pm 8.16$ & $35.95 \pm 7.32$ & $35.64 \pm 7.03$ & $35.60 \pm 7.72$ \\
\hline - Jarak tl pubis- dada (mm) & $51.27 \pm 12.76$ & $54.74 \pm 9.86$ & $50.39 \pm 11.73$ & $52.12 \pm 13.26$ \\
\hline Bobot badan (gr) & $1464.26+293.58$ & $1658.19+339.63$ & $1646.92+297.89$ & $1492.93+371.26$ \\
\hline
\end{tabular}

Sumber : data primer (2019)

Induk ayam kampung berjengger walnut paling banyak ditemukan yaitu sebesar 36,45\%. Warna bulu ayam jengger walnut sangat variatip. Warna bulu hitam paling banyak ditemukan yaitu sebanyak 7,19\%, diikuti warna lurik $6.23 \%$, putih $3.83 \%$, keemasan $3,1 \%$, liar 2,91dan abu 1,19\%. Warna bulu hitam dipengaruhi oleh gen E, sedangkan gen e+ menyebabkan bulu lurik dan gen I/W+ menyebabkan warna bulu putih (Untari dkk., 2013).

Ayam kampung merupakan ayam Indonesia yang masih memiliki gen asli sebanyak lebih kurang 50\% dengan ciriciri pola bulu liar (e+), kerlip bulu keemasan (ZS), warna shank hitam (Zid) 
dan bentuk jengger pea $(\mathrm{P})$, sedangkan $50 \%$ sisanya merupakan campuran dari bangsa ayam unggul Eropa dan Amerika seperti Australope, New Hampshire, White Cornish, Rhode Island Red, White Leghorn dan Barred Plymouth Rock (Nishida et al.,1980).

Warna cuping telinga sebanyak $17,5 \%$ berwarna merah dan $6.96 \%$ berwarna putih. Khaeruddinsyah (2018) menyatakan bahwa rata-rata persentase warna cuping telinga ayam kampung betina didominasi warna merah $(92,59)$ persen. Menurut Crawford (1990), sebagian besar breed ayam mempunyai cuping telinga berwarna merah, tetapi breed dari kelas mediteranean (Leghorn, Minorca, dan Spanish) mempunyai cuping berwarna putih. Bangsa-bangsa ayam Mediteranean bercuping telinga putih adalah tipe ayam petelur (Syakir, 2018). Sedikitnya ayam kampung yang bercuping telinga putih karena nenek moyang ayam Mediteranean sudah punah dan sekarang menjadi ayam kelas Asia (Tarigan, 2010).

Warna shank didominir warna kuning yaitu sebanyak 16,08\%, diikuti warna putih sebanyak 5,99\% dan hitam sebanyak 2,39\%. Warna shank kuning dipengaruhi oleh adanya pigmen karotenoid pada epidermis dan tidak adanya pigmen melanin pada epidermis maupun dermis. Apabila kedua pigmen tersebut tidak ada, maka shank berwarna putih (Ensminger, 1992). Individu dengan cakar berwarna putih/kuning dipengaruhi oleh gen Id, sedangkan cakar hitam dipengaruhi gen id (Somes, 1988).

Warna kulit didominir warna putih yaitu sebesar 14,87\% dan warna kuning hanya 9,59\%. Menurut Crawford (1990) bahwa warna kulit kuning disebabkan oleh keturunan berkulit kuning dan makanan yang mengandung xantophyl.

Ayam kampung dengan jengger tipe walnut memiliki tinggi jengger, panjang shank, panjang tibia, panjang femur, jarak antara dua tulang pubis dan jarak tulang pubis dengan tulang dada paling pendek dibandingkan tipe jengger lain. Tinggi jengger dapat digunakan untuk mengetahui sifat produksi ayam. Mukhtar dan Khan (2012) menyatakan bahwa sifat-sifat produksi ayam petelur berkorelasi positif dengan ukuran jengger. Semakin tinggi ukuran jengger, maka semakin banyak hormon reproduksi yang tersimpan (Tarigan, 2010).

Mansjoer (1985) menyatakan bahwa panjang shank merupakan penduga paling tepat untuk bobot badan. Pertumbuhan tulang berkaitan erat dengan pertumbuhan otot pada ayam. Tulang tibia memiliki ukuran yang lebih panjang dari tulang femur. Tulang tibia berkorelasi positip dengan bobot badan (Sartika, 2007). Semakin panjang tulang femur maka semakin banyak daging yang melekat (James,1990) yang disitasi Khaeruddinsyah ( 2018).

Yuwanta (2004) menyatakan bahwa tulang pubis digunakan untuk mendeteksi produksi telur. Jarak ideal ukuran tulang pubis pada ayam kampung yaitu sekitar dua jari orang dewasa yang artinya jika dibuat dalam satuan ukuran mm sekitar 30,00 mm. Semakin panjang jarak tulang pubis maka kemampuan ayam bertelur semakin baik (Tarigan, 2010).

Jarak antara tulang pubis dengan tulang dada digunakan untuk menduga kemampuan produksi telur. Ayam yang telah memasuki fase produksi memiliki 
jarak antara tulang pubis dengan tulang dada sekitar 3-4 jari orang dewasa. Kemampuan produksi yang tinggi dapat dilihat setelah memasuki fase layer dan masa puncak produksi, untuk mengetahui kemampuan bertelur dengan produksi tinggi dapat digunakan hubungan lebar antara lebar tulang pubis dengan tulang dada sebagai acuan untuk menyeleksi ayam yang potensial sebagai penghasil telur yang baik (Khairul,2016).

Ayam berjengger walnut memiliki bobot badan 1.646,92 $\pm 297,89 \mathrm{gr}$ hampir sama dengan ayam jengger rose yang mencapai bobot badan tertinggi 1.658,19+339.63. Buwono, (2007) menyatakan bahwa bobot badan dipengaruhi oleh kualitas dan kuantitas pakan yang dikonsumsi. Banyaknya pakan yang dikonsumsi akan memberikan pengaruh terhadap pertambahan bobot badan yang dihasilkan. Kandungan zat-zat pakan yang seimbang dan cukup sesuai dengan kebutuhan sangat diperlukan untuk pertumbuhan yang optimal. Menurut Kurniawan, dkk (2012) bahwa faktor yang mempengaruhi pertumbuhan yaitu faktor genetik, jenis kelamin, umur, penyakit dan manajemen pemeliharaan.

Menurut Daryono dkk. (2012) ayam tipe pedaging umumnya mengacu pada prtumbuhan otot. Masa percepatan pertumbuhan terjadi sebelum ternak mengalami pubertas (dewasa kelamin) yang kemudian setelahnya terjadi perlambatan (Agustina, dkk, 2013). Pada ayam petelur dengan berat badan pre-layer yang lebih tinggi akan bertelur lebih cepat dibanding ayam dengan berat badan sedang maupun ringan (Yusri, 2015).

\section{KESIMPULAN DAN SARAN}

\section{Kesimpulan}

Sifat kualitatif dan morfometrik ayam kampung di Pulau Lombok sangat beragam. Terjadi introgresi (pemasukan darah) ayam ras unggul luar negeri. Ditemukan 4 tipe jengger Pea (24.46), Rose (8.64), Walnut (36.45) dan Tunggal (30.45). Mormometrik tertinggi terdapat pada ayam tipe jengger rose.

\section{Saran}

Keragaman sifat kualitaif dan morfometrik ayam kampung di Pulau Lombok dapat digunakan sebagai bahan seleksi untuk perbaikan mutu genetik yang berkelanjutan. Seleksi yang tepat diharapkan akan terjadi respon yang positif untuk meningkatkan heritabilitas.

\section{DAFTAR PUSTAKA}

Agustina, D; Iriyanti, N dan Mugiyono, S. 2013. Pertumbuhan dan Konsumsi Pakan pada Berbagai Jenis Itik Lokal Betina yang Pakannya disuplementasi Probiotik. Jurnal Ilmiah Peternakan, 1(2): 691-698

Akhsan. 1995. analisa Permintaan Ayam Kampung oleh Pedagang Ayam Bakar (Goreng) Kaki Lima di Kodya Dati II Mataram. Skripsi. Fakultas Peternakan. UNRAM. Mataram.

Buwono, F. A. 2007. Pengaruh Tingkat Protein Pakan dan Frekuensi Pemberian Pakan terhadap Kinerja Itik Mojosari (Anas Domesticus) Jantan Periode Awal. Skripsi. Universitas Brawijaya Malang. 
Crawford, R.D. 1990. Origin and Historyof Poultry Spesies. Dalam R.D. Crawford (ed) : Poultry Breeding and Genetics. Pp. : $239-$ 256. Elsevier Science Publishing Company. Inc. Canada.

Daryono, B.S., R. Satriya, Z. Rohmah dan Y. Erwanto. 2012. Penguatan Industri Bibit Unggas Nasional Melalui Produksi Indukan Gama Ayam Lokal Unggul. Jurnal Ilmu Pengetahuan dan Teknologi Tepat Guna. UGM. ISSN 2089-2721.

Ensminger, M.A. 1992. Poultry Science (Animal Agriculture Series). 3th Edition. Interstate Publisher, Inc. Danville, Illinois.

Hardjosubroto, W. 1994. Aplikasi Pemuliaan Ternak Di Lapangan. Grasindo. Jakarta.

Khaeruddinsyah. 2018. Fenotipe Ayam Kampung Di Kecamatan Alas, Alas Barat, Dan Utan Kabupaten Sumbawa. Publikasi Ilmiah. Progam Studi Peternakanprogram Studi Peternakanfakultas Peternakanuniversitas Mataram Mataram.

Khairul, R. 2016. Hubungan Antara Lebar Tulang Pubis Dengan Tulang Dada Terhadap Bobot Telur, Indeks Telur, Dan Jumlah Produksi Telur Strain Lohmann Brown. Thesis, Universitas Brawijaya.

Kurnianto, E., S. Sutopo, E. Purbowati, E.T. Setiatin, D. Samsudewa and T. Permatasari. 2013. Multivariate analysis of morfphological traits of local goats in Central JavaIndonesia. Iranian J. App. Anim. Sci. 3 (2):361- 367.
Kurniawan, L.A; Atmomarsono, U dan Mahfudz, L. D. 2012. Pengaruh berbagai Frekuensi Pemberian Pakan dan Pembatasan Pakan terhadap Pertumbuhan Tulang Ayam Broiler. Jurnal Agromedia, 30 (2): 14-22.

Lestari; Rahma Jan dan N.Kt.D.Haryani. 2007. Kontribusi Gen Na terhadap Kualitas Daging Ayam Taliwang. Laporan Penelitian. Fakultas peternakan UNRAM.

Mansjoer, S.S. 1985. Pengkajian Sifatsifat Produksi Ayam Kampung serta Persilangannya dengan Rhode Island Red. Disertasi. Fakultas Psca Sarjana Institute Pertnian Bogor. Bogor.

Mayora,W.I. 2017. Performa Ayam Kub Periode Starter Pada Pemberian Ransum dengan Protein Kasar yang Berbeda. Skripsi. Jurusan Peternakan, Fakultas PertanianUniversitas Lampung

Melani, 2010. Karakteristik Sistem Pemeliharaan Ayam Kampung Dan Ayam Leher Gundul Di Kabupaten Subang, Jawa Barat. Skripsi. Fakultas Peternakan Institut Pertanian Bogor.

Mukhtar, N. dan S.H. Khan. 2012. Comb : An Important Reliable Visual Ornamental Trait For Selection on Chicken. World's Poult. Sci. Vol. $68: 425-431$. 
Nishida,T., K. Nozawa, Y.Hayasi, T.Hsyiguchi and S.S. Mansjoer. 1982. Body Measurement and Analysis On Eksternal Genetic Characters of Indonesian Native Fowl. The Orig. Ang Phy. Of Ind. Nat. Liv. III : 73 - 83

Ridhwan, M. 2012. Tingkat Keanekaragaman Hayati Dan Pemanfaatannya Di Indonesia. Jurnal Biology Education Vol 1, No 1 (2012)

Samariyanto. 2005. Arah Pengembangan Pembibitan Ayam Lokal di Indonesia Prosiding Lokakarya Nasional Inovasi Teknologi Pengembangan Ayam Lokal. Puslitbang Peternakan

Sartika T. dan S. Iskandar. 2007. Mengenal Plasma Nutfah Ayam Indonesia dan Pemanfaatannya. Edisi pertama. Balai Penelitian Ternak, Bogor.

Singarimbun, M. dan S. Efendi. 1989. Metodelogi Penelitian Survei. LP3ES: Jakarta.Halaman 156

Somes, N. 1988. Molecular Evolutionary Genetics. Columbia University Press, New York.

Subekti, K. dan F. Arlina. 2011. Karakteristik Genetik Eksternal Ayam Kampung di Kecamatan Sungai Pagu Kabupaten Solok Selatan. Jurnal Ilmiah Ilmu-ilmu Peternakan. November 2011. Vol. XIV. No. 2.

Suryo.1994. Genetika. Gadjah Mada University Press.
Sutoyo, 2010. Eksploitasi spesies flora dan fauna berlebihan akan menimbulkan kelangkaan dan kepunahan spisies. Buana Sains Vol 10 N0 2: 101-106, 2010.

Syakir, A. 2018. Identifikasi Karakteristik Sifat Kualitatif Ayam Gaga Di Kabupaten Sidrap Sulawesi Selatan. Skripsi. Universitas Hasanudin.

Tarigan, R.T. 2010. Karakteristik Sifat Kualitatif Dan Kuantitatif Ayam Walik Di Sumedang Dan Bogor. Skripsi. Departemen Ilmu Produksi Dan Teknologi Peternakan Fakultas Peternakan Institut Pertanian Bogor.

Warwick, E.J., J.M. Astuti dan W. Hardjosubroto. 1995. Pemuliaan Ternak. Edisi kelima. Gadjah Mada University Press, Yogyakarta.

Williamson, G. dan W. J. A. Payne. 1993. Pengantar Peternakan di Daerah Tropis (Diterjemahkan oleh S.G.N.D. Darmadja). Edisi ke-1. Gadjah Mada University Press. Yogyakarta.

Yusri. 2015. Performa Ayam Ras Petelur Pada Periode Awal Bertelur Dengan Kombinasi Berat Badan Pre-Layer Dan Pemberian Jumlah Pakan Yang Berbeda. Skripsi. Fakultas Peternakan Universitas Hasanuddin. Makassar.

Yuwanta. T. 2004. Dasar Ternak Unggas. Penerbit Kanisius Yogyakarta. 
Zaenuri, A. Zaini, W. Werdiningsih dan T.

Sjah. 2016. Keragaman Pangan Lokal Di Pulau Lombok untuk Menunjang Pengembangan Pariwisata. Agritech. Vol. 36, No. 2. Maret 2016.

Zein, M.S.A dan Sulandari, S. 2008. Keragaman Genetik Ayam Lombok Berdasarkan Sekuen DLOOP DNA Mitokondria. Jurnal Ilmu Ternak dan Veteriner. 13(4):307-314.

Zelditch, M.; D. Swiderski; D.H. Sheets; and W. Fink. 2004. Geometric Morphometrics for Biologists: A Primer. Academic Press, New York. 